\title{
PRODUCTION OF LIGNOLYTIC AND FEED-BACK TYPE ENZYMES BY PHLEBIA RADIATA ON DIFFERENT MEDIA
}

\author{
J. Rogalski, ${ }^{1}$ J. FiedureK ${ }^{2}$ and A. LeONOWicZ ${ }^{1}$ \\ ${ }^{1}$ Department of Biochemistry, Maria Curie Skłodowska University, M. C.-Sklodowska \\ Square 3, 20-031 Lublin, Poland \\ ${ }^{2}$ Department of Industrial Microbiology, Maria Curie Skłodowska University, \\ Akademicka 19 Str., 20-033 Lublin, Poland
}

(Received: January 15, 2000; accepted: May 12, 2000)

\begin{abstract}
Low molecular-weight compounds, structurally related to lignin, increase the production of laccase, lignin peroxidase, manganese dependent peroxidase, and feed-back type enzymes such as glucose oxidase, cellobioso-quinone oxidoreductase, and glyoxal oxidase in the culture of the white rot fungus Phlebia radiata growing on different carbon sources.
\end{abstract}

Keywords: Phlebia radiata - veratric acid - vanillic acid - ferulic acid - cellulose - cellobiose - glucose - GOD - laccase - ligninase - MnP - glyoxal oxidase - $\mathrm{CBH}$

\section{INTRODUCTION}

Many diverse microbes, including anaerobic and aerobic bacteria, and fungi degrade cellulose. The bulk of cellulose, however, is not accessible to the degradative enzymes until its coating of the natural plastic lignin is not removed [9]. Lignin is by far the most abundant aromatic substance present in the biosphere. It is a phenylpropanoid polymer composed of nonhydrolyzable $\mathrm{C}-\mathrm{C}$ and $\mathrm{C}-\mathrm{O}-\mathrm{C}$ bonds. The aromatic rings are substituted with no, one, or two methoxyl groups while the interunit linkages lack stereoregularity [48].

The most widely studied white-rot wood destroying fungi, belonging primarily to the Basidiomycetes, are characterized by their ability to mineralize all the structural components of wood $[9,29]$. Aromatic carboxylic acids, such as vanillic, syringic, isovanillic and veratric acids, are released in considerable amounts during white-rot decay in wood [7]. Some of these lignin monomers are also produced by Phlebia radiata as a secondary metabolite during the synthesis from glucose [46]. Veratryl alcohol produced by many white-rot species has been postulated to be a low-molecular mediator which can be involved in lignin depolymerization as an agent [14].

Most of the research directed to understand the biochemistry of lignin degradation has carried out with Phanerochaete chrysosporium. In lignin degradation and production of lignin modifying enzymes, Phlebia radiata shows many similarities to

*Corresponding author; E-mail: rogal@hermes.umcs.lublin.pl 
Ph. chrysosporium. It proved to be a more effective degrader of ${ }^{14} \mathrm{C}$ (ring) labeled poplar lignin than Phanerochaete and other strains belonging to the white-rot group $[15,16]$.

Enzymatic disruption of the lignin barrier is an aerobic process in which all acting enzymes can be divided into three groups. The first one comprises enzymes attacking the lignin directly. In this process, extracellular phenoloxidases are involved, including lignin peroxidase (LiP; EC 1.11.1.14), manganese-dependent peroxidase (MnP; EC 1.11.1.13), laccase (LAC; EC 1.10.3.2), horseradish like peroxidase (HLP; EC 1.11.1.7), as well as intracellular dioxygenases such as protocatechuate 3,4dioxygenase (P34D; EC 1.13.11.3), 1,2,4-trihydroxybenzene 1,2-dioxygenase (TBH12D), and catechol 1,2-dioxygenase (C12D; EC 1.13.11.1). The second group of enzymes includes superoxide dismutase (SOD; EC 1.15.1.1) and glyoxal oxidase (GLO; EC 1.2.3.5). These enzymes cooperate with the first group of enzymes but never attack lignin on their own. The third group consists of glucose 1-oxidase (GOD; EC 1.1.3.4), aryl alcohol oxidase (AAO; EC 1.1.3.7, e.g., veratric alcohol oxidase-VAO), pyranose 2-oxidase (P2O; EC 1.1.3.10), cellobiose: quinone oxidoreductase (CBH; EC 1.1.5.1), and cellobiose dehydrogenase (CDH; EC 1.1.99.18) [35]. This latter group is often called "feed-back" type as these enzymes play a key role in combining metabolic chains of carbohydrates and lignin biodeterioration in wood.

This report constitutes a supplement of the first part of investigation [47] in which the authors detected the transformation of specifically-labeled ${ }^{14} \mathrm{C}$ in the different position of veratric acid, methanol, and formaldehyde by Phlebia radiata growing on the media with different carbon sources. The report also discusses the production of ligninase, Mn-peroxidase, laccase and the three kind of extracellular $\mathrm{H}_{2} \mathrm{O}_{2}$ producing enzymes such as glucose oxidase (GOD or P2O), glyoxal oxidase, and cellobiosequinone oxidoreductase during fungal cultivation.

\section{MATERIALS AND METHODS}

\section{Organism and cultural conditions}

Phlebia radiata Fr no79 [ATCC 64658] was isolated at the Department of Microbiology, University of Helsinki [16] and maintained on 2\% (w/v) malt agar slants. The preparation of inoculum was carried out in accordance with [16]. After 6 days of growing at $28^{\circ} \mathrm{C}$ the mycelial mats were broken in a Warning Blender to give a homogenized inoculum suspension. After inoculation with $4 \%(\mathrm{v} / \mathrm{v})$ of the homogenate, $100 \mathrm{ml}$ conical flasks - each containing $10 \mathrm{ml}$ of ADMS-LN medium with $1 \%(\mathrm{w} / \mathrm{v})$ glucose or $4 \%(\mathrm{w} / \mathrm{v})$ glucose or $1 \%(\mathrm{w} / \mathrm{v})$ cellobiose or $1 \%(\mathrm{w} / \mathrm{v})$ of Avicell as a carbon source - were incubated in a stationary manner at $28^{\circ} \mathrm{C}$. Veratric or vanillic or ferulic acids in the concentration of $1 \mathrm{mM}$ were added to each inoculated flask on the 3rd day of its growth. The flasks were then cultivated in a stationary manner at $28{ }^{\circ} \mathrm{C}$ for the next 7 days. 


\section{Determination of enzyme activities}

Enzyme activities were measured using a Shimadzu 160A UV-VIS programmable spectrophotometer. Culture fluids of parallel sample flasks (2-3 flasks) were separately filtered through Whatman No. 4 filter paper. Ligninase activity was determined following the oxidation of veratryl alcohol to veratraldehyde at $310 \mathrm{~nm}$ at $37^{\circ} \mathrm{C} \mathrm{pH}$ $3.0[50]$.

Laccase activity was determined with syringaldazine (4-hydroxy-3,5-dimethoxybenzaldehyde azine) using a modified method [32] of Ander and Eriksson [2]. Laccase and lignin peroxidase activity are expressed in katals $\left(\mathrm{mol} \mathrm{s}^{-1}\right)$. Manganesedependent peroxidase (Mn-peroxidase) activity was assayed by means of the phenolred method [12] modified by omitting the $\mathrm{NaOH}$ supplement and measuring the absorbance change at $520 \mathrm{~nm}$ for 5 minutes at $30{ }^{\circ} \mathrm{C}$ [37]. Mn-peroxidase activity is expressed in $\mathrm{A}_{520 \mathrm{~nm}} \min ^{-1} \mathrm{l}^{-1}$. Cellobiose: quinone oxidoreductase activity was determined by measuring reduction of 3,5-di-tert-butyl-o-benzoquinone at $420 \mathrm{~nm}$ in the presence of cellobiose [3]. One enzyme unit was defined as the amount of enzyme that reduced $1 \mu \mathrm{mol}$ quinone per minute at $\mathrm{pH} 4.5$ and $25^{\circ} \mathrm{C}$. Glucose oxidase was determined directly in liquids by means of the methods described by Lloyd and Whelan [36] with our own modification as in [43]. One unit of the enzyme was defined as the amount that oxidizes $1 \mu \mathrm{mol} \beta$-D-glucose to D-gluconic acid $\min ^{-1}$ at $37^{\circ} \mathrm{C}$ and $\mathrm{pH}$ 5.0. Glyoxal oxidase activity was measured according to [27] by modified peroxidase-coupled assay with phenol red as the peroxidase substrate as in [42]. One enzyme unit was defined as the amount that produces $1 \mu \mathrm{mol} \mathrm{H}_{2} \mathrm{O}_{2} \min ^{-1}$ at $\mathrm{pH}$ 6.0 and $25^{\circ} \mathrm{C}$.

\section{Chemicals}

Reference compounds 3,4-dimethoxybenzoic acid (veratric acid), 4-hydroxy-3methoxycinnamic acid (ferulic acid) were obtained from Fluka (Buchs, Switzerland); 4-hydroxy-3-methoxybenzoic acid (vanillic acid) and methylglyoxal (acetylformaldehyde) were obtained from Sigma (St. Louis, USA); 3,4-dimethoxybenzyl alcohol (veratryl alcohol), 3,5-di-tert-butyl-o-benzoquinone and syringaldazine (4hydroxy-3,5-dimethoxybenzaldehyde azine) were obtained from Aldrich (Milwaukee, Wisconsin USA); phenol red was obtained from Merck (Darmstadt, FRG).

\section{RESULTS AND DISCUSSION}

The wood degrading fungi are highly specialized in the utilization of their substrate wood. In most cases, the white-rot fungi remove lignin, cellulose, and hemicellulose simultaneously, perhaps implying that the enzymatic degradation of different wood components is interconnected. In spite of the recent progress in lignin biodegradation 

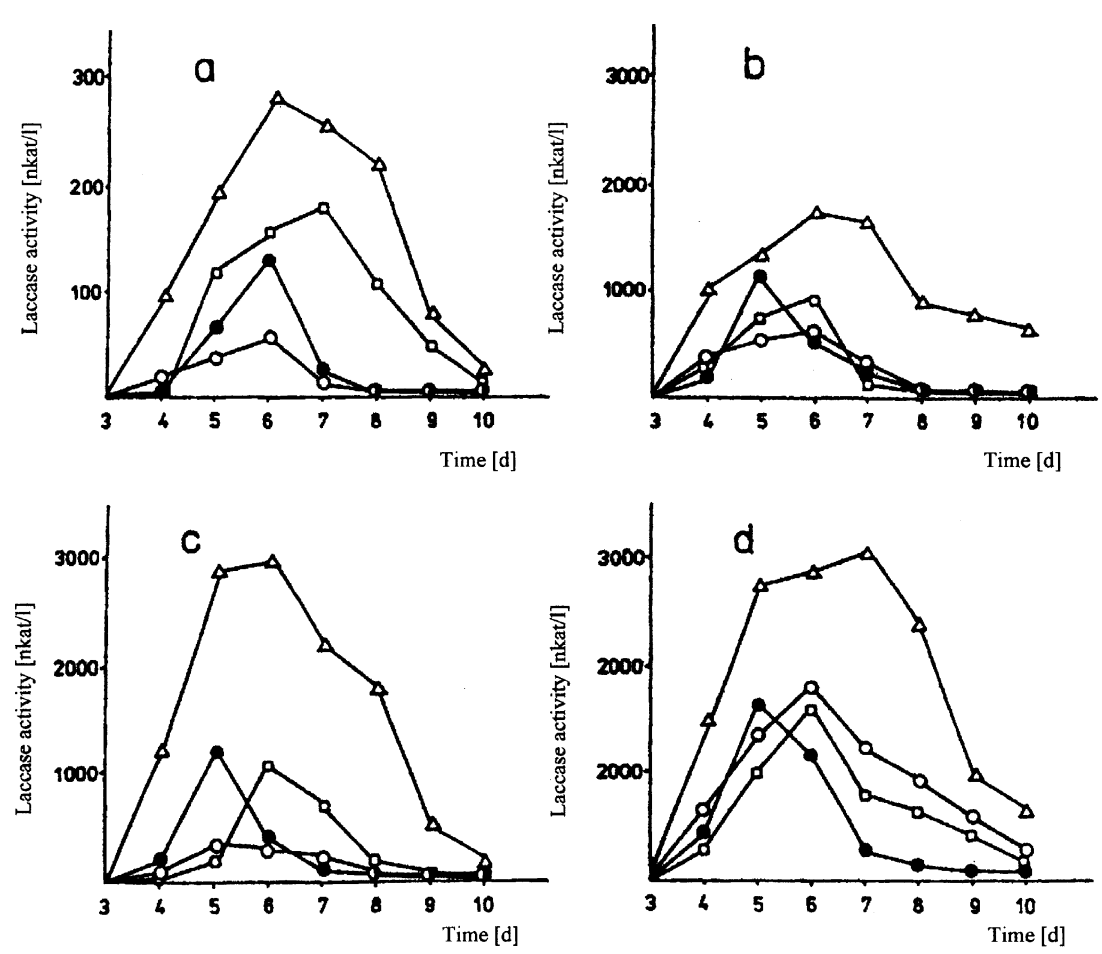

Fig. 1. Production of laccase by Phlebia radiata (a) in control condition; (b) after addition of $1 \mathrm{mM}$ vanillic acid; (c) $1 \mathrm{mM}$ veratric acid, and (d) $1 \mathrm{mM}$ ferulic acid on the media with $1 \%$ glucose $(0-0) ; 4 \%$ glucose $(\bullet-\bullet) ; 1 \%$ cellobiose $(\triangle-\triangle)$ and $1 \%$ cellulose $(\square-\square)$ as the only carbon source

research, more information is still needed especially (i) on the succession of enzymes or factors involved in the degradation of macromolecular native or isolated lignin, and (ii) on the relative importance of individual ligninolytic enzymes in the whole degradation process [15]. White-rot fungi to which Phlebia radiata belongs produce extracellular lignin-modifying enzymes, the best characterized of which are laccase, $\mathrm{LiP}$ and MnP.

Laccase, first discovered by a Yoshida in 1883 [56], is an enzyme which is involved in lignin demethylation [31], in subsequent decomposition of lignin macromolecule [39], in $C \alpha-C \beta$ cleavage of phenolic lignin substructure [23] as well as in the aromatic ring cleveage [24]. The influence of further addition of aromatic substances such as vanillic, veratric and ferulic acids on the synthesis of cellulase complex system by $P h$. radiata [45] and also on the lignolytic enzymes production on ADMS-LN medium (2 mM-N; $56 \mathrm{mM}$ glucose) [44] was studied. In both cases the distinct influence of terminated activities under used inducers were observed.

Fraser et al. [11] found that the hyphae of the wood-rotting Coriolus versicolor Basidiomycete in culture are surrounded by a layer of mucilage. In conditions of 
excess carbon source such a glucose, sucrose, or cellobiose, the secretion of polysaccharides increases and is released into the culture medium. They also found that in this condition, natural immobilization of laccase was observed; perhaps also that of other enzymes on this hyphael mucilage layer. This immobilization effect may be compared to enzyme activity in a solid-phase or nonaqueous environment.

$P h$. radiata growing on ADMS-LN medium with different carbon sources such as glucose (1 or $4 \%$ ), cellobiose (1\%), and cellulose (1\% of Avicell) showed very clear odds in the degradation of veratric acid labeled on different functional group isotopes [47]. Figure 1 shows the change of laccase activity on the same media. As it was shown the laccase activity on glucoses media was observed on the 2nd day after induction of $P$. radiata cultures by $1 \mathrm{mM}$ veratric acid (Fig. 1c). Similar effect was detected after using vanillic and ferulic acids (Fig. 1b, d). In all cases the laccases activities were highest on the medium with cellobiose (almost twice as on the control ADMS-LN with $1 \%$ glucose) while some of them increased with time. The effect of inhibition by higher glucose concentration (4\%) was also observed.

Lignin peroxidase, which is induced by veratryl alcohol as well as by carbon and nitrogen-starvation conditions [50], catalyses several oxidations in the alkyl side chains of lignin-related compounds [29], $\mathrm{C} \alpha-\mathrm{C} \beta$ cleavage in the side chains of lignin sub-units [18], oxidation of benzyl alcohols to aldehydes or ketones [50], intradiol cleavage of phenylglycol structures, and hydroxylation of benzolic methylene groups $[38,49]$. This enzyme also showed specific demethoxylating and ring cleaving activity $[28,51]$. Figure 2 presents the synthesis of lignin peroxidase during the cultivation of $P$ h. radiata. The maxima of its activities were observed between the 7 th to 9th day of its growth. The highest value was obtained on the basal ADMS medium with $1 \%$ of glucose under all used inducers. Distinct inhibition by $4 \%$ glucose in case of vanillate and ferulate but not so much in case of veratrate was observed. Cellobiose and cellulose had also repressing effect on the ligninase activity.

Another enzyme which can act in lignin degradation process is Mn-peroxidase. It was found in the extracellular growth fluid of $P$. chrysosporium [21, 30], Trametes versicolor [53] and Phlebia radiata [17, 22]. It contains a single protoheme IX with high-spin ferric iron and functions by oxidizing $\mathrm{Mn}^{2+}$ to $\mathrm{Mn}^{3+}$ which, in turn, oxidizes phenols to phenoxy radicals [12]. Like laccase, Mn peroxidases appear to function as phenol oxidizing enzymes. In addition, it may also be involved in $\mathrm{H}_{2} \mathrm{O}_{2}$ production in the process of glutathione, dithiothreitol, or NADPH oxidation [5, 41]. Figure 3 presents the results of the induction of $P h$. radiata MnP by vanillic, veratric, and ferulic acids on media with different carbon sources. In all cases, in comparison to the control condition, including cellobiose medium, where a strong inhibition is observed, little stimulation of the enzyme production can be observed. The maximum of $\mathrm{MnP}$ can be observed between the 6th to 8th day of its growth, which is slightly earlier than in case of ligninases (Figs 2, 3).

The discovery that extracellular $\mathrm{H}_{2} \mathrm{O}_{2}$ is required for lignin degradation $[4,9,35]$ and that the process is accelerated in the presence of cellulose or its oligomers [1, 19, 20] prompted investigations into its origin. Various possibilities were considered. First of all, the function of some cytosolic fungal enzymes was analyzed, e.g. alco- 

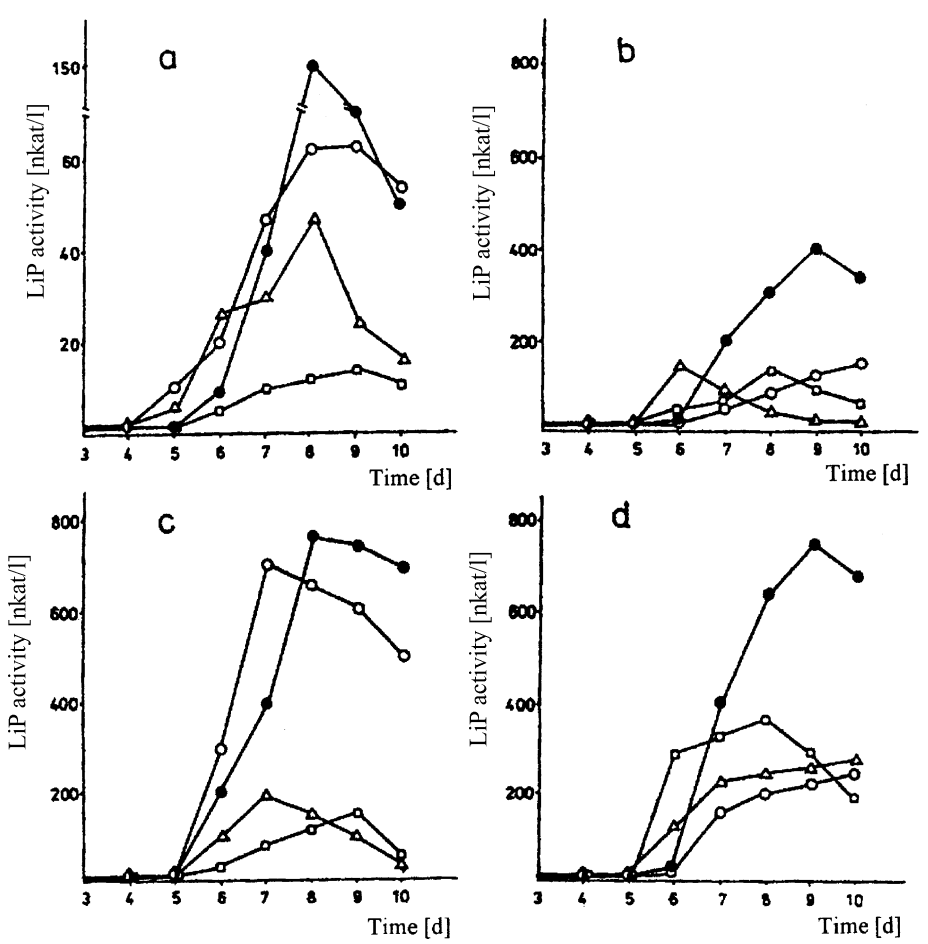

Fig. 2
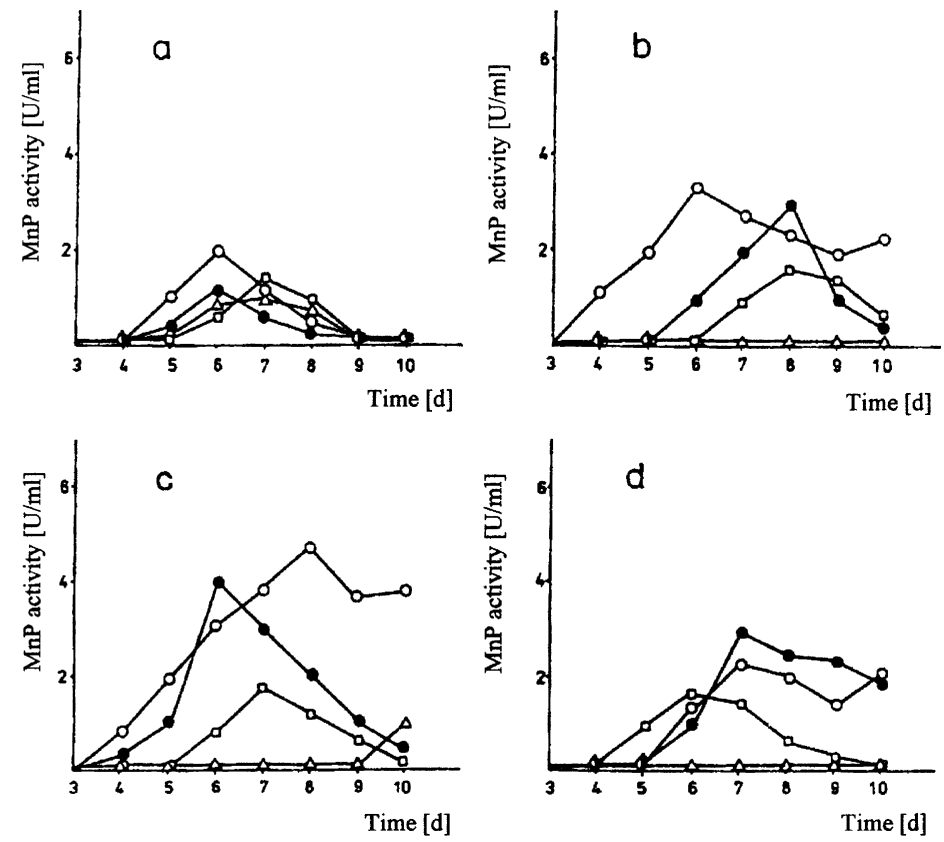

Fig. 3

Acta Biologica Hungarica 52, 2001 

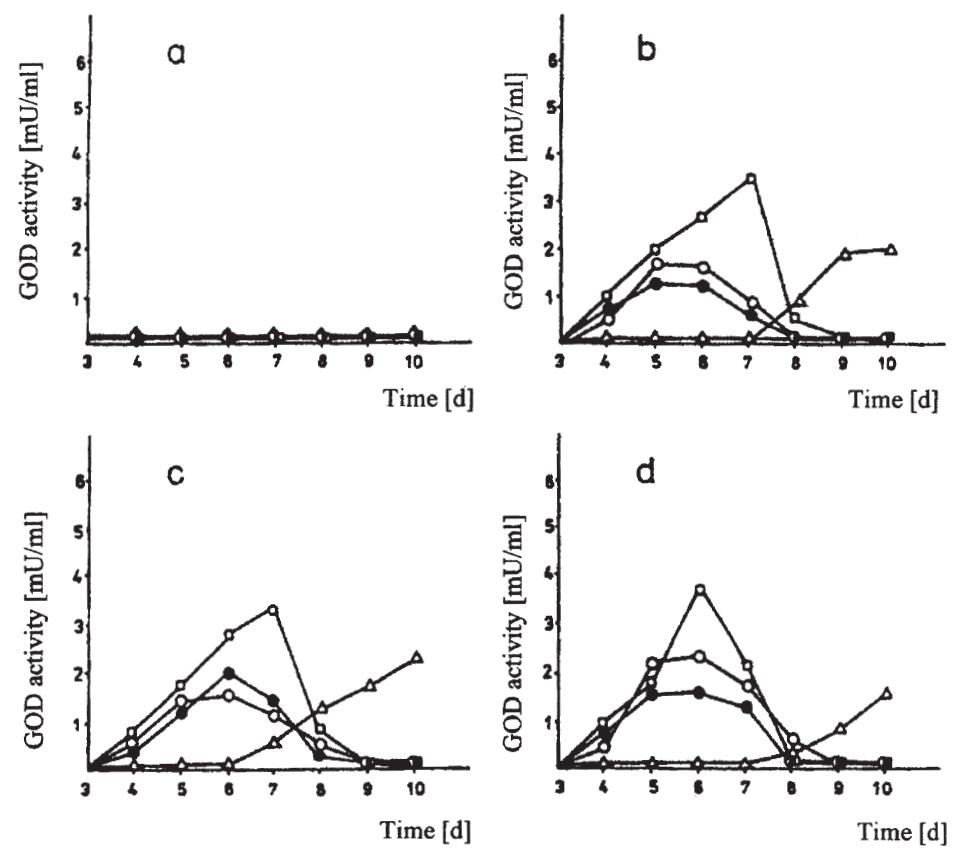

Fig. 4. Production of glucose oxidase by Phlebia radiata (a) in control condition; (b) after addition of 1 $\mathrm{mM}$ vanillic acid; (c) $1 \mathrm{mM}$ veratric acid, and (d) $1 \mathrm{mM}$ ferulic acid on the media with $1 \%$ glucose ( ${ }_{-} \mathrm{O}$ ); $4 \%$ glucose $(\bullet-\bullet) ; 1 \%$ cellobiose $(\triangle-\triangle)$ and $1 \%$ cellulose $(\square-\square)$ as the only carbon source

hol oxidase $[6,10]$, glucose-2-oxidase (pyranose 2-oxidase) $[8,52]$, glucose-1-oxidase $[25,26]$, cellobiose-quinone oxidoreductase $[54,55]$, fatty acyl CoA oxidase [13], and glyoxal oxidase [27]. Among all the enzymatic systems under investigation, only CBQ [3], GOD [33, 34, 40], and glyoxal oxidase [27] can function both in the cytoplasm and extracellularly. The production of these enzymes was presented in Figs 4, 5, 6 .

Fig. 2. Production of lignin peroxidase by Phlebia radiata (a) in control condition; (b) after addition of $1 \mathrm{mM}$ vanillic acid; (c) $1 \mathrm{mM}$ veratric acid, and (d) $1 \mathrm{mM}$ ferulic acid on the media with $1 \%$ glucose $\left(\bigcirc_{-} \mathrm{O}\right)$; $4 \%$ glucose $(\bullet-\bullet)$; $1 \%$ cellobiose $(\triangle-\triangle)$ and $1 \%$ cellulose $(\square-\square)$ as the only carbon source

Fig. 3. Production of manganese dependent peroxidase by Phlebia radiata (a) in control condition; (b) after addition of $1 \mathrm{mM}$ vanillic acid; (c) $1 \mathrm{mM}$ veratric acid, and (d) $1 \mathrm{mM}$ ferulic acid on the media with $1 \%$ glucose ( $\left.\bigcirc_{-} \mathrm{O}\right) ; 4 \%$ glucose $(\bullet-\bullet) ; 1 \%$ cellobiose $\left(\triangle_{-} \triangle\right.$ ) and $1 \%$ cellulose $(\square-\square)$ as the only carbon source 

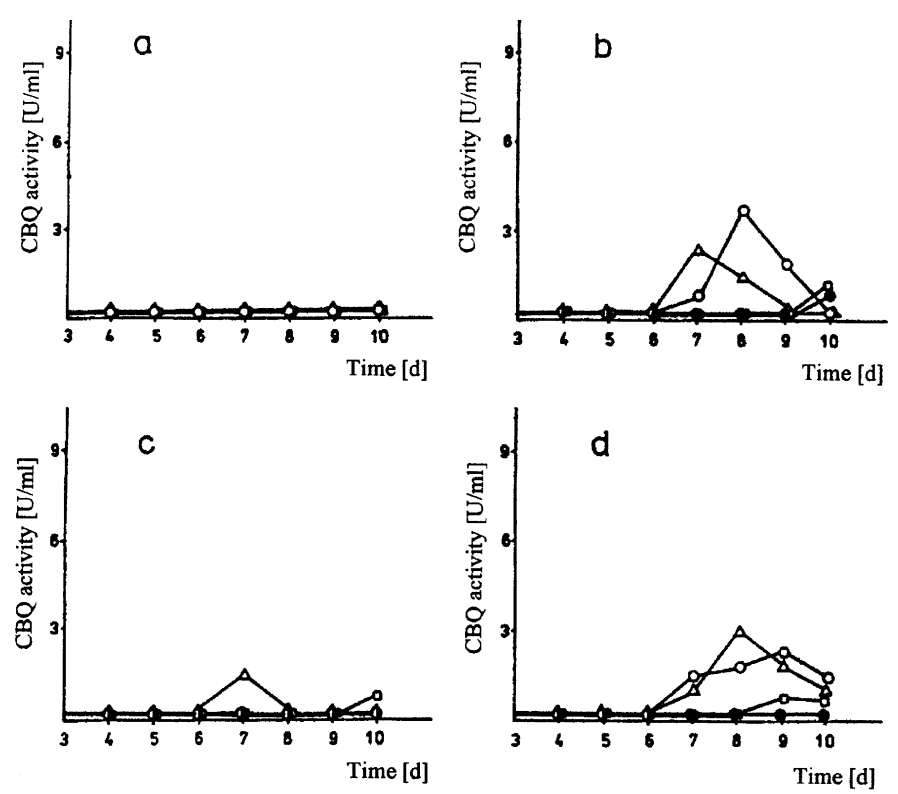

Fig. 5. Production of cellobiose-quinone oxidase by Phlebia radiata (a) in control condition; (b) after addition of $1 \mathrm{mM}$ vanillic acid; (c) $1 \mathrm{mM}$ veratric acid, and (d) $1 \mathrm{mM}$ ferulic acid on the media with $1 \%$ glucose ( $\left.0_{-} 0\right)$; $4 \%$ glucose $(\bullet-\bullet) ; 1 \%$ cellobiose $(\triangle-\triangle)$ and $1 \%$ cellulose $(\square-\square)$ as the only carbon source
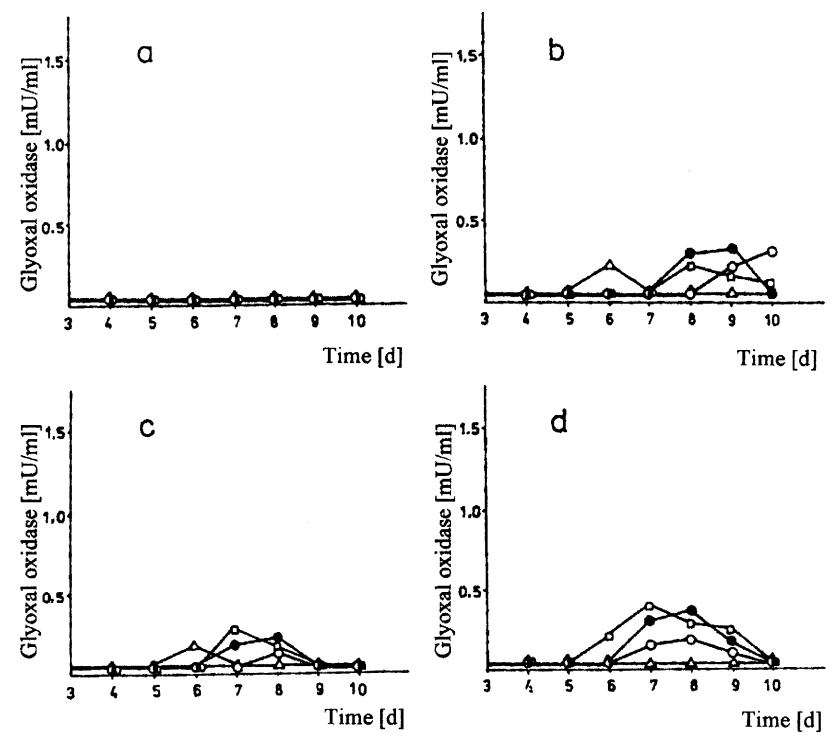

Fig. 6. Production of glyoxal oxidase by Phlebia radiata (a) in control condition; (b) after addition of 1 $\mathrm{mM}$ vanillic acid; (c) $1 \mathrm{mM}$ veratric acid, and (d) $1 \mathrm{mM}$ ferulic acid on the media with $1 \%$ glucose $\left(O_{-} \mathrm{O}\right) ; 4 \%$ glucose $(\bullet-\bullet) ; 1 \%$ cellobiose $\left(\triangle_{-} \triangle\right)$ and $1 \%$ cellulose $(\square-\square)$ as the only carbon source 
Glucose oxidase activity was stimulated by all used aromatic substances, showing the strongest activities on the medium with cellulose as a solid carbon source. The peak of these activities was observed between the 6th and 8th day of their growth (e.g. 3rd-4th day after the induction). Some differences can be observed in glucose oxidase activity on cellobiose medium where this activities can occur very late, on the 9th or the 10th day of the fungal growth (Fig. 4). The CBQ activity can be observed in Ph. radiata cultures on the media with cellobiose, $4 \%$ glucose, and cellulose (Fig. 5). Veratric acid used as inducer resulted in a peak on the 7th day of the growth on cellobiose medium. On the 10th day a slight increase in CBQ activity was observed. A similar effect on the cellulose medium was observed in case of vanillic and ferulic acids used as inducers. Also, the peak of CBQ activity on cellobiose medium under induction of vanillate and ferulate on the 7th-8th day was observed. Additionally, in case of $4 \%$ glucose media induced by vanillate and ferulate on the 8th-9th day of the growth CBQ activity occurred. No activities on basal ADMS-LN $(1 \%$ glucose) were observed. Finally, the glyoxal oxidase activity, which was capable of using simple aldehyde, $\alpha$-hydroxycarbonyl or $\alpha$-dicarbonyl compounds as substrates, was determined (Fig. 6). The activities manifested in trace amounts between the 7th to 9th day of the $P h$. radiata growth on all media and inducers. They were observed at the same time as the ligninase activities (Figs 2,6) and the evolution of ${ }^{14} \mathrm{CO}_{2}$ from alifatic $\mathrm{C}_{3}$-carbon of ferulate [data not published].

On the basis of these tests carried out on Ph. radiata, it is possible to place tentatively the fungus in the class of white rot fungi, which produce predominantly inducible enzymes directly attacking lignin, such as laccase, $\mathrm{LiP}$, and $\mathrm{MnP}$, as well as feed-back type enzymes, such as GOD, CBQ, and GLO in the degradation of ligninocellulosics. The fungus may also act as a selective lignin degrader since the majority of known selective lignin degraders belong to this group.

\section{ACKNOWLEDGEMENTS}

This work was supported in part by the Polish Committee for Scientific Investigations SPUB-M-SPRUE/DZ280/2000 and European Community (the RTD5EC project ICAZ-CT-2000-10050 and $\mathrm{BW} / \mathrm{BiNoZ}$ project).

\section{REFERENCES}

1. Ander, P., Eriksson, K.-E. (1975) Influence of carbohydrates on lignin degradation by the white-rot fungus Sporotrichum pulverulentum. Svensk Papperstidn. 78, 642-652.

2. Ander, P., Eriksson, K.-E. (1976) The importance of phenol oxidase activity in lignin degradation by the white-rot fungus Sporotrichum pulverulentum. Arch. Microbiol. 136, 1-6.

3. Ander, P., Eriksson, K.-E. (1977) Selective degradation of wood components by white-rot fungi. Physiol. Plant. 41, 239-248.

4. Ander, P., Marzullo, L. (1997) Sugar oxidoreductases and veratryl alcohol oxidase as related to lignin degradation. J. Biotechnol. 53, 115-131.

5. Asada, Y., Miyabe, M., Kikkawa, M., Kuwahara, M. (1987) An extracellular NADH-oxidizing peroxidase produced by a lignin-degrading basidiomycete Phanerochaete chrysosporium. J. Ferment. Technol. 65, 483-487. 
6. Buswell, J. A. (1986) Methanol metabolism in Phanerochaete chrysosporium. In: Ander, P. (ed.), Proc. 3th Intern. Conf. Biotechnol. Pulp Paper Ind. STFI, Stockholm, pp. 20-23.

7. Chen, C.-L., Chang, H.-M. (1985) Chemistry of lignin biodegradation. In: Higuchi, T. (ed.), Biosynthesis and biodegradation of wood. Academic Press, San Diego, pp. 535-556.

8. Eriksson, K.-E., Petersson, B., Volc, J., Musilek, V. (1986) Formation and partial characterization of glucose-2-oxidase a $\mathrm{H}_{2} \mathrm{O}_{2}$ producing enzyme in Phanerochaete chrysosporium. Appl. Microbiol. Biotechnol. 23, 257-262.

9. Eriksson, K.-E., Blanchette, R. A., Ander, P. (1990) Microbial and enzymatic degradation of wood and wood components. Springer-Verlag, Berlin, Heidelberg, pp. 1-407.

10. Eriksson, K.-E., Nishida, A. (1989) Methanol oxidase of Phanerochaete chrysosporium. Methods of Enzymology 161, 322-326.

11. Fraser, M. A., Gallagher, I. M., Evans, C. S. (1986) Characterization of the surface polysaccharide of Coriolus versicolor and its effect on polyphenoloxidase activity. In: Ander, P. (ed.), Proc. 3th Intern. Conf. Biotechnol. Pulp Paper Ind. STFI, Stockholm, pp. 187-188.

12. Glenn, J. K., Gold, M. H. (1985) Purification and characterization of an extracellular Mn(II)-dependent peroxidase from the lignin-degrading basidiomycete, Phanerochaete chrysosporium. Arch. Biochem. Biophys. 242, 329-241.

13. Greene, R. V., Gould, J. M. (1984) Fatty acyl-coenzyme A oxidase activity in nycelia from the lignin degrading fungus Phanerochaete chrysosporium. Biochem. Biophys. Res. Commun. 118, 437-443.

14. Harvey, P. J., Schoemaker, H. E., Palmer, J. M. (1986) Veratryl alcohol as a mediator and the role of radical cations in lignin biodegradation by Phanerochaete chrysosporium. FEBS Lett. 195, 242-246.

15. Hatakka, A. (1994) Lignin-modifying enzymes from selected white-rot fungi: production and role in lignin degradation. FEMS Microbiol. Rev. 13, 125-135.

16. Hatakka, A. I., Uusi-Rauva, A. (1983) Degradation of ${ }^{14} \mathrm{C}$-labelled poplar wood lignin by selected white-rot fungi. Eur. J. Appl. Microbiol. Biotechnol. 17, 235-242.

17. Hatakka, A., Mohammadi, O., Lundell, T. (1989) The potential of white-rot fungi and their enzymes in the treatment of lignocellulosic feed. Food Biotechnol. 3, 45-58.

18. Higuchi, T. (1986) Catalytic pathways and role of ligninases for the degradation of lignin substructure models by white rot fungi. Wood Res. (Kyoto) 73, 68-81.

19. Hiroi, T., Eriksson, K.-E., Stenlund, B. (1976) Microbial degradation of lignin Part 2. Influence of cellulose upon the degradation of calcium lignosulphonates of various molecular sizes by the whiterot fungus Pleurotus ostreatus. Svensk Papperstidn. 79, 162-166.

20. Hiroi, T., Eriksson, K.-E. (1976) Microbial degradation of lignin Part 1. Influence of cellulose on the degradation of lignins by the white-rot fungus Pleurotus ostreatus. Svensk Papperstidn. 79, 157-161.

21. Huynh, V.-B., Crawford, R. L. (1985) Novel extracellular enzymes (ligninases) of Phanerochaete chrysosporium. FEMS Lett. 28, 119-123.

22. Karhunen, E., Niku-Paavola, M.-L., Kantelinen, A. (1989) Mn-dependent peroxidase from lignin degrading white-rot fungus Phlebia radiata. Arch. Biochem. Biophys. 279, 25-31.

23. Kawai, S., Umezawa, T., Shimada, M., Higuchi, T., Kaide, K., Morohoshi, N., Haraguchi, T. (1987) $\mathrm{C} \alpha-\mathrm{C} \beta$-cleavage of phenolic $\beta-1$ lignin substructure model compound by laccase of Corioluc versicolor. Mokuzai Gakkaishi 33, 792-797.

24. Kawai, S., Umezawa, T., Shimada, M., Higuchi, T. (1988) Aromatic ring cleavage of 4,6-di(tertbutyl)guaiacol, a phenolic lignin model compound, by laccase of Coriolus versicolor. FEBS Letters 236, 309-311.

25. Kelley, R. L., Reddy, A. (1986) Purification and characterization of glucose oxidase from lignolytic cultures of Phanerochaete chrysosporium. J. Bacteriol. 166, 269-274.

26. Kelley, R. L., Reddy, A. (1988) Glucose oxidase of Phanerochaete chrysosporium. Methods in Enzymology 161, 307-316.

27. Kersten, P. J., Kirk, T. K. (1987) Involvement of a new enzyme, glyoxal oxidase, in extracellular $\mathrm{H}_{2} \mathrm{O}_{2}$ productin by Phanerochaete chrysosporium. J. Bacteriol. 169, 2195-2201. 
28. Kirk, T. K., Kersten, P. J., Mozuch, M. D., Kalyanaraman, B. (1986) Ligninase of Phanerochaete chrysosporium. Mechanism of its degradation of the non-phenolic arylglycerol $\beta$-aryl ether substructure of lignin. Biochem. J. 236, 279-287.

29. Kirk, T. K., Farell, R. L. (1987) Enzymatic "combustion": The microbiological degradation of lignin, Ann. Rev. Microbiol. 41, 465-505.

30. Kuwahara, M., Glenn, J. K., Morgan, M. A., Gold, M. H. (1984) Separation and characterization of two extracellular $\mathrm{H}_{2} \mathrm{O}_{2}$-dependent oxidases from ligninolytic cultures of Phanerochaete chrysosporium. FEBS Lett. 169, 247-250.

31. Leonowicz, A., Grzywnowicz, K., Malinowska, M. (1979) Oxidative and demethylating activity of multiple forms of laccase from Pholiota mutabilis. Acta Biochim. Polon. 26, 431-434.

32. Leonowicz, A., Grzywnowicz, K. (1981) Quantitative estimation of laccase forms in some white-rot fungi using syringaldazine as a substrate. Enzyme Microb. Technol. 3, 55-58.

33. Leonowicz, A., Rogalski, J., Szczodrak, J. (1985) Cooperation of fungal enzymes in transformation of lignocellulose. In: Proc. 13-th Intern. Congress of Biochemistry, Amsterdam (Holland), p. 608.

34. Leonowicz, A., Rogalski, J., Szczodrak, J., Fiedurek, J. (1986) The possible key role of glucose oxidase in transformation of lignocellulose. In: P. Ander (ed.), Proc. 3rd Intern. Conf. Biotechnol. Pulp Paper Ind. STFI, Stockholm, pp. 160-162.

35. Leonowicz, A., Matuszewska, A., Luterek, J., Ziegenhagen, D., Wojtaś-Wasilewska, M., Cho, N.-S., Hofricgter, M., Rogalski, J. (1999) Biodegradation of lignin by white rot fungi. Fungal Gen. Biol. 27, $175-185$.

36. Lloyd, J. B., Whelan, W. J. (1969) Enzymatic determination of glucose in the presence of maltose. Anal. Biochem. 30, 467-470.

37. Lundell, T., Leonowicz, A., Rogalski, J., Hatakka, A. (1990) Formation and action of lignin-modyfying enzymes in cultures of Phlebia radiata supplemented with veratric acid. Appl. Environ. Microbiol. 56, 2623-2629.

38. Lundell, T. (1996) Ligninolytic system of the white-rot fungus Phlebia radiata: Lignin model compound studies. Ph. D. thesis, University of Helsinki, Helsinki, pp. 1-90.

39. Lunquist, K., Kristersson, P. (1985) Exhaustive laccase catalysed oxidation of a lignin model compound (vanillyl glycol) produces methanol and polymeric quinoid products. Biochem. J. 229, 277-279.

40. Maltseva, O. V., Myasoedova, N. M., Leontievsky, A. A., Golovieva, L. A. (1986) Characteristic of the ligninolytic system of Panus tigrinus 144. In: Golovleva, A. (ed.), Proc. Sov.-Finn. Sem. Microb. Degradation Lignocellul. Raw Matter. USSR Acad.Sci., Pushchino, pp. 65-74.

41. Paszczynski, A., Huynh, V.-B., Crawford, R. L. (1985) Enzymatic activities of an extracellular, manganese-dependent peroxidase from Phanerochaete chrysosporium. FEMS Microbiol. Lett. 29, 37-41.

42. Pick, E., Keisari, Y. (1980) A simple colorimetric method for the measurement of hydrogen peroxide produced by cells in culture. J. Immunol. Methods 38, 161-170.

43. Rogalski, J., Dawidowicz, A., Fiedurek, J., Leonowicz, A. (1990) The controlled porous glass (CPG) with epoxy groups as support for affinity chromatography. II.Modified CPG as support of substrates or coenzyme of glucose oxidase (GOD) for its purification and immobilization. Acta Biotechnol. 10, 289-298.

44. Rogalski, J., Lundell, T., Leonowicz, A., Hatakka, A. (1992) Influence of lignin-related aromatic compounds on the production of ligninolytic enzymes by Phlebia radiata. In: Kennedy, J. F., Phillips, G. O., Williams, P. A. (eds), Lignocellulosics: science, technology, development and use. Ellis Horwood, New York, London, pp. 55-60.

45. Rogalski, J., Hatakka, A., Wojtas-Wasilewska, M., Leonowicz, A. (1993) Cellulolytic enzymes of the ligninolytic white-rot fungus Phlebia radiata. Acta Biotechnol. 13, 41-45.

46. Rogalski, J., Niemenmaa, O., Uusi-Rauva, A., Hatakka, A. (1996) De novo synthesis of aromatic compounds and metabolism of ${ }^{14} \mathrm{C}$-glucose in the presence and absence of phenolic compounds by Phlebia radiata. In: Srebotnik, E., Messner, K. (eds), Proc. 6th Intern. Conf. Biotechnol. Pulp Paper Ind. Facultas-Universitätsverlag, Vienna, Austria, pp. 451-454.

47. Rogalski, J., Hatakka, A., Leonowicz, A. (1999) Demethylation and degradation of $\left[{ }^{14} \mathrm{C}\right]$-labelled veratric acids by Phlebia radiata. Acta Microbiol. Polon. 49, 207-216. 
48. Sakakibara, A. (1983) Chemical structure of lignin related mainly to degradation process. In: Higuchi, T., Chang, H.-M., Kirk, T. K. (eds), Recent advances in lignin biodegradation research. UNI Publisher, Tokyo, pp. 12-33.

49. Schoemaker, H. E., Meijer, E. M., Leisola, M. S. A., Haemmerli, S. D., Waldner, R., Sanglard, D., Schmidt, H. W. H. (1989) Oxidation and reduction in lignin biodegradation. In: Lewis, N. G., Paice, M. G. (eds), Plant cell wall polymers. Biogenesis and biodegradation. American Chemical Society, Washington, pp. 454-471.

50. Tien, M., Kirk, T. K. (1984) Lignin-degrading enzyme from Phanerochaete chrysosporium: purification, characterization, and catalytic properties of a unique $\mathrm{H}_{2} \mathrm{O}_{2}$ requiring oxygenase. Proc. Natl. Acad. Sci. USA, 81, 2280-2284.

51. Umezama, T., Shimada, M., Higuchi, T., Kusai, K. (1986) Aromatic ring cleavage of beta-O-4 lignin substructure model dimers by lignin peroxidase of Phanerochaete chrysosporium. FEBS Lett. 205, 287-292.

52. Volc, J., Denisova, N. P., Nerud, F., Musilek, V. (1985) Glucose-2-oxidase activity in mycelial cultures of Basidiomycetes. Folia Microbiol. 30, 141-147.

53. Waldner, R., Leisola, M. S. A., Fiechter, A. (1988) Comparison of ligninolytic activities of selected white rot fungi. Appl. Microbiol. Biotechnol. 29, 400-407.

54. Westermark, U., Eriksson, K.-E. (1974) Carbohydrate-dependent enzymatic quinone reduction during lignin degradation. Acta Chemica Scandin. B28, 204-208.

55. Westermark, U., Eriksson, K.-E. (1974a) Cellobiose:quinone oxidoreductase a new wood-degrading enzyme from white-rot fungi. Acta Chemica Scandin. B28, 209-214.

56. Yoshida, H. (1883) Chemistry of lacquer (Urushi). J. Chem. Soc. 43, 472-486. 